\title{
Characterisation and quantification of phosphorus release from profundal bottom sediments in two dimictic lakes during summer stratification
}

\author{
Uwe SELIG* and Günter SCHLUNGBAUM ${ }^{\dagger}$ \\ University of Rostock, Institute of Aquatic Ecology, Albert Einstein Str. 3, D-18051 Rostock, Germany \\ *e-mail corresponding author: uwe.selig@biologie.uni-rostock.de
}

\begin{abstract}
Phosphorus release from the sediment in two dimictic lakes was compared during the summer stratification. Soluble reactive phosphate (SRP) and also $\mathrm{NH}_{4}^{+}$were released from the anoxic sediment into the water column in Lake Dudinghausen and Lake Tiefer. The sediment released $\mathrm{NH}_{4}^{+}$and SRP only when oxygen and nitrate/nitrite were absent. Besides the SRP concentration in the hypolimnion, P-binding in the upper sediment changed during summer stratification in both lakes. In Lake Dudinghausen a decrease in the redox-sensitive bound $P$ was observed in the upper sediment. Only in this lake does the classic anoxic P-release by reduction of the FeOOH-phosphate complex play a dominant role. In both lakes, however, the contents of organically bound P increased in the upper $0.5 \mathrm{~cm}$ layer during the summer stratification. P-release was calculated using four different methods. The calculated P-release during summer stratification varied between 15 and $207 \mathrm{mg} \mathrm{P} \mathrm{m}^{-2} y^{-1}$ in Lake Dudinghausen and between 22 and $55 \mathrm{mg} P \mathrm{~m}^{-2} y^{-1}$ in Lake Tiefer.
\end{abstract}

Key words: phosphorus release, phosphorus fractionation, sediment, redox condition, dimictic lakes

\section{INTRODUCTION}

In terms of the net balance over a year, lake sediments accumulate nutrients, especially phosphorus. Prelease and P-bindings, however, may vary seasonally. Phosphorus release from the sediment is often a significant component of the phosphorus budget of lakes. Large amounts of $\mathrm{P}$ are released under anoxic conditions during summer stratification and phosphorus usually accumulates as soluble reactive phosphate (SRP) in the hypolimnion (Nürnberg 1987). Diffusion of SRP occurs through well-established chemical and thermical gradients directly affecting the concentration in the epilimnion and enhancing phytoplankton primary production (Gliwicz 1979). Therefore, P-release plays an important role in the regulation of phytoplankton growth and in the trophic level of dimictic lakes (Welch \& Cooke 1995; Boers et al. 1998).

The classic model of P-release from anoxic sediments is the reduction of FeOOH-phosphate complexes (Einsele 1936, 1938; Mortimer 1941, 1942). Golterman (2001) discussed the results of Mortimer not only as an interpretation of Fe-bound P-release under anoxic conditions; he also described the possibility that an organic constituent forms a part of the adsorbing complex in oxidised muds. Besides these theories, other processes for anoxic P-release have been described:

- solubilization of apatite by a drop of the $\mathrm{pH}$-value (Golterman 1998);

- mineralisation of sedimentary organic matter by bacterial activity (Gächter et al. 1988; Sinke et al. 1990);

- mineralisation of phytate (Golterman et al. 1998);
- release of polyphosphate by sediment bacteria (Hupfer et al. 1995a).

The remobilisation of phosphorus from the sediment, however, is probably controled by its speciation. Therefore, knowing the total phosphorus content of the sediment is not sufficient for defining the amount of $\mathrm{P}$ that can be released, as described by Nürnberg (1988) and Sas (1989). P-speciation in sediments can be resolved using a technique of sequential chemical extraction (Williams et al. 1971; Golterman 1982; Psenner et al. 1984). The use of the chemical extraction has been critically discussed (Hartikainen 1979; Barbanti et al. 1994; Ruban et al. 1999). The loosely adsorbed fraction and the redox-sensitive fraction are particularly subject to mobilisation. Boström et al. (1985) characterised the organically bound phosphorus as being the most dynamic fraction in the surface sediment. The characterisation of the bioavailable fractions is especially difficult. Hieltjes \& Lijklema (1980) defined the $\mathrm{NH}_{4} \mathrm{Cl}$ fraction as labile inorganic phosphorus. DePinto et al. (1981) found a strong correlation between the $\mathrm{NaOH}$ fraction and the sediment $\mathrm{P}$ available to support algal growth as determined in a bioassay. Many investigators defined the sum of two or three fractions as mobilized phosphorus (Boström 1984; Psenner et al. 1984). Penn et al. (1995) calculated the diagenesis of $\mathrm{P}$ from measurements of labile P-components and a constant ratio of labile to refractory phosphorus in freshly deposited sediment.

The present study compares the P release in two dimictic lakes in Northeast-Germany, each with an anaerobic hypolimnion but different trophic state. The mechanisms of P-release were investigated and quanti- 


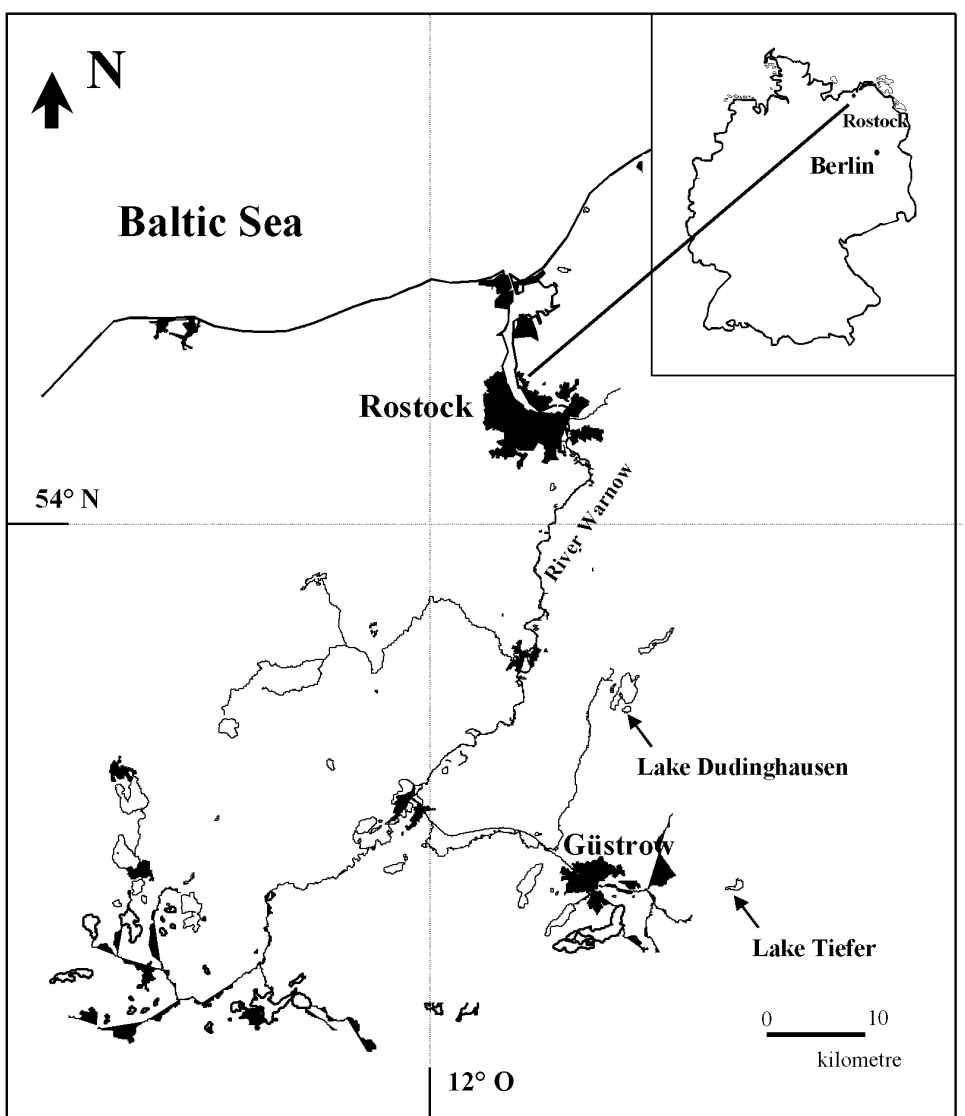

Fig. 1. Locations of the Lake Dudinghausen (DUD) and Lake Tiefer (TIF) in Mecklenburg-Vorpommern, northern Germany.

fied. This approach involved investigating the $\mathrm{P}$ concentration in the hypolimnion and the variability of phosphorus bound in the uppermost sediment before, during, and after the summer stratification. Benthic Prelease was calculated using different methods and compared in the two lakes.

\section{MATERIALS AND METHODS}

\subsection{Study sites}

The Lake Dudinghausen (DUD) and Lake Tiefer (TIF) are dimictic lakes in Mecklenburg Vorpommern (North Germany), approximately $30 \mathrm{~km}$ and $40 \mathrm{~km}$ south of Rostock $\left(54^{\circ} \mathrm{N}, 12^{\circ} \mathrm{E}\right)$ at the Baltic Sea (Fig. 1). Their main morphometric and limnological parameters are presented in table 1. Based on measurements 1997-2001 Lake DUD was classified as mesotrophic, whereas Lake TIF showed a low eutrophic state according to the German standard (LAWA 1998).

\subsection{Water analysis}

The investigation was carried out at monthly intervals from March to November in 1998 at the deepest points of each lake. Vertical profiles of temperature, oxygen and $\mathrm{pH}$ were taken using the multiprobe Torphil 406. After membrane filtration $(0.45 \mu \mathrm{m})$ ammonium, nitrite and nitrate were determined after Rohde \& Nehring (1979).

Tab. 1. Morphometric and limnological characteristics of the two lakes, * seasonal variation from March to November $1998 / 1999 \mathrm{n}=18{ }^{(1)}$ : based on morphometry (LAWA 1998). ${ }^{(2)}$ : based on German standard (LAWA 1998)

\begin{tabular}{lcc}
\hline & Lake TIF & Lake DUD \\
\hline Surface area (ha) & 15.9 & 18.8 \\
Volume $\left(\mathrm{m}^{3} \times 10^{6}\right)$ & 1.69 & 1.29 \\
Mean depth $(\mathrm{m})$ & 10.7 & 6.9 \\
Maximum depth $(\mathrm{m})$ & 30.6 & 15.2 \\
Catchment area in ha & 144 & 25 \\
Reference trophic state ${ }^{(1)}$ & mesotrophic & mesotrophic \\
& & \\
Total phosphorus $\left(\mu \mathrm{g} 1^{-1}\right)^{*}$ & $21-97$ & $32-80$ \\
Secchi depth $(\mathrm{m})^{*}$ & $0.7-2.2$ & $0.6-3.6$ \\
Chlorophyll- $a\left(\mu \mathrm{g} \mathrm{1^{-1 }}\right)^{*}$ & $2-13$ & $2-6$ \\
Trophic classification $1999 / 2000^{(2)}$ & eutrophic (e1) & mesotrophic \\
\hline
\end{tabular}

Soluble reactive phosphorus (SRP) was analysed by applying the molybdenum blue method in a flow- 
Tab. 2. The five steps in the extraction procedure of Psenner et al. (1984) and the corresponding P-fractions (SRP = soluble reactive phosphorus; NRP $=$ non reactive phosphorus).

\begin{tabular}{|c|c|c|c|c|}
\hline step & extraction solvent & $\begin{array}{c}\text { Time, } \\
\text { temperature }\end{array}$ & $\begin{array}{l}\text { corresponding } \\
\text { P-fraction }\end{array}$ & bounding forms \\
\hline 1 & $\mathrm{H}_{2} \mathrm{O}$ (distilled water) & $0.3 \mathrm{~h}, 25^{\circ} \mathrm{C}$ & $\mathrm{TP}$ & $\begin{array}{l}\text { soluble phosphorus in pore water, unstable at the surface, } \\
\text { adsorbed phosphates, algae-available phosphates }\end{array}$ \\
\hline 2 & $\begin{array}{c}\mathrm{BD}(0.11 \mathrm{M}) \\
\text { (Bicarbonate-dithionite) }\end{array}$ & $0.5 \mathrm{~h}, 40^{\circ} \mathrm{C}$ & SRP & Redox-sensitive P, mainly bound to Fe-hydroxides \\
\hline 3 & $\begin{array}{c}\mathrm{NaOH}(1 \mathrm{M}) \\
\text { (sodiumhydroxide) }\end{array}$ & $16 \mathrm{~h}, 25^{\circ} \mathrm{C}$ & SRP & $\begin{array}{l}\mathrm{P} \text { bound to metal oxides mainly of } \mathrm{Al} \text { and } \mathrm{Fe} \text {, sorptive-bound } \\
\text { sorbed } \mathrm{P} \text { on metals and organic compounds }\end{array}$ \\
\hline & & & NRP & $\begin{array}{l}\text { organic } \mathrm{P} \text {, e.g. } \mathrm{P} \text { in microorganisms, detritus, humic } \\
\text { compounds, poly-P, P-lipid }\end{array}$ \\
\hline 4 & $\begin{array}{c}\mathrm{HCl}(0.5 \mathrm{M}) \\
\text { (Hydrochloric acid) }\end{array}$ & $16 \mathrm{~h}, 25^{\circ} \mathrm{C}$ & SRP & carbonate- and apatite-bound phosphorus \\
\hline 5 & $\mathrm{NaOH}(1 \mathrm{M})$ & $8 \mathrm{~h}, 80^{\circ} \mathrm{C}$ & $\mathrm{TP}$ & residual $\mathrm{P}$ \\
\hline
\end{tabular}

through system at $660 \mathrm{~nm}$ according to Malcolm-Lawes \& Koon (1990). Alkalinity was determined by titration with $0.1 \mathrm{~N} \mathrm{HCl}$ according to the standardized German methodology (DEV 1992).

\subsection{Sediment analysis}

Sediments were sampled in March, May, September and November 1998 with an UWITEC-corer at the deepest location. Five cores were taken at the deepest location and the same depth horizons of the cores were mixed. With this sampling procedure the spatial variation of the depth region of the lakes were excluded and cannot overlay the seasonal variation. The obtained sediment cores were cut into the following seven horizons: $0-0.5 \mathrm{~cm} / 0.5-1 \mathrm{~cm} / 1-2 \mathrm{~cm} / 2-3 \mathrm{~cm} / 3-4 \mathrm{~cm} / 4-$ $5 \mathrm{~cm}$ and $9-10 \mathrm{~cm}$. All sediment analyses were carried out in triplicate.

The sediments were dried at a temperature of $105{ }^{\circ} \mathrm{C}$ to determine the dry weight (dw) in \% of wet weight (ww) (Schlungbaum 1979). After homogenisation, the amounts of organic carbon $\left(\mathrm{C}_{\text {org }}\right)$, inorganic carbon $\left(\mathrm{C}_{\text {inorg }}\right)$ and total nitrogen $(\mathrm{TN})$ were determined based on the dry weight with a $\mathrm{C} / \mathrm{N}$ Analyser Vario EL after Verardo et al. (1990).

Total phosphorus (TP) in the sediments was determined as the $\mathrm{HCl}$-soluble portion of the residues after combustion (at $550{ }^{\circ} \mathrm{C}$ ), using the method described by Andersen (1976). The total iron (TFe) and aluminium (TAl) levels were determined from the same extract. After reduction to $\mathrm{Fe}^{2+}$, TFe was analysed photometrically at $560 \mathrm{~nm}$ as ferrozine colour complex (Stookey 1970). Following complex formation with chromazurol$\mathrm{S}$ in acetate buffer, the TAl content was measured photometrically at $560 \mathrm{~nm}$ (Dunemann \& Schwedt 1984).

Pore water profiles of phosphate were obtained by centrifugation $\left(6000 \mathrm{~g}, 10{ }^{\circ} \mathrm{C}, 20 \mathrm{~min}\right)$ and filtration (cellulose-acetate, $0.45 \mu \mathrm{m}$ ). SRP and $\mathrm{NH}_{4}{ }^{+}$were measured as described above for water samples. The dissolved $\mathrm{Fe}(\mathrm{DFe})$ was determined with the method of $\mathrm{TFe}$ analysis in sediments. The dissolved organic $\mathrm{P}$ (DOP) was calculated as the difference between dis- solved TP and SRP (Sinke et al. 1990). Dissolved TP was measured according to Nakamura et al. (1980).

\subsection{P-speciation of sediment}

In order to determine the different forms of phosphorus in the sediments, the extraction method of Psenner et al. (1984) was used. Different solvents used in a certain sequence allow conclusions about the Pbindings (Tab. 2). All analyses were carried out in triplicate. The soluble reactive phosphorus (SRP) was determined using an extraction agent. Total phosphorus (TP) was determined by means of acid hydrolysis under UV radiation. The non-reactive phosphorus (NRP) is defined as the difference between the total phosphorus and the soluble reactive phosphorus. With this extraction, the following P-species are separated: labile $\mathrm{P}$ $\left(\mathrm{H}_{2} \mathrm{O}-\mathrm{TP}\right)$, redox-sensitive $\mathrm{P}$ (bicarbonate-dithionite fraction, BD-SRP), adsorbed P and Al-P (NaOH-SRP), organically bound $\mathrm{P}$ (NaOH-NRP), Ca-bound $\mathrm{P}$ ( $\mathrm{HCl}-$ $\mathrm{SRP})$, residual $\mathrm{P}$ (NaOHhot-TP). The margin of error was estimated to be half the distance between the extreme values. The errors were usually below $2 \%$, except for the sum of extractable $\mathrm{P}$ that was $4 \%$.

\subsection{Calculations of P-release}

The benthic P-release from the profundal sediment under anoxic conditions was calculated using four methods: (1) molecular diffusion between SRP in the water column and pore water as according to Fick's Law (Sinke et al. 1990), (2) mean accumulation rate of SRP in the hypolimnion at the end of summer stratification, (3) diagenetic release of labile P-components according to the prognosis of Penn et al. (1995), (4) potential release of $\mathrm{Fe}-$ and $\mathrm{Mn}$-bound $\mathrm{P}$ according to Gonsiorczyk et al. (2001). The calculation of method (3) and (4) considered the uppermost $2 \mathrm{~cm}$ sediment layer. The calculation of the diagenetic release of labile $\mathrm{P}$ components (3) used two different definitions of refractory phosphorus compounds: variant $\mathrm{A}$ is based on the definition of refractory $\mathrm{P}$ as the sum of $\mathrm{HCl}$-extractable $\mathrm{P}$ and residual $\mathrm{P}$ (Penn et al. 1995). Variant B includes the $\mathrm{NaOH}-$ NRP fraction. 

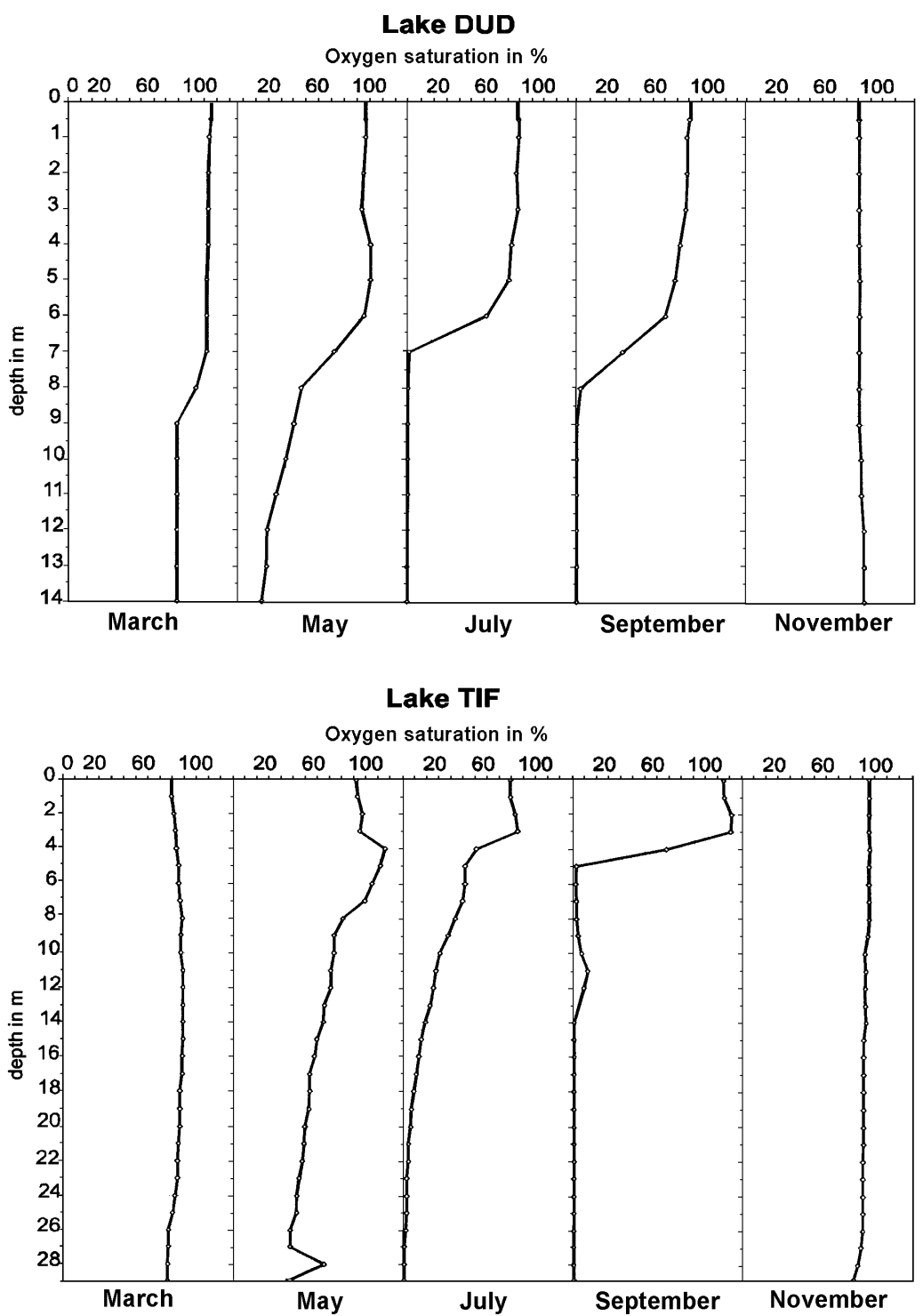

Fig. 2. Oxygen saturation in the vertical profile of Lake DUD and Lake TIF during 1998.

\section{RESULTS}

\subsection{Seasonal variation of oxygen and nutrients in the hypolimnion}

The thermal stratification of the lake begins in May and ends in October/November after a period of approximately 150-170 days for both lakes. In May oxygen decreases in the hypolimnion below $25 \%$ oxygen saturation; from July to October/November the hypolimnion of both lakes was anoxic (Fig. 2). With the autumn circulation the hypolimnion returned to oxic conditions.

With the onset of anoxic conditions in the hypolimnion, the concentrations of $\mathrm{NH}_{4}^{+}$and SRP increased dramatically in Lake DUD (Fig. 3). The nitrate concentration was also very low (undetectable) at this time (Tab. 3). Nitrate was found until July in Lake TIF, and only in the absence of nitrate SRP and $\mathrm{NH}_{4}{ }^{+}$increase in the hypolimnion. During summer stratification the concentrations of $\mathrm{NH}_{4}^{+}$and SRP remained stable and increased somewhat at the end of stratification. The release of both nutrients was two- to three-fold higher in Lake DUD than in Lake TIF. We found a strong positive correlation between the $\mathrm{NH}_{4}^{+}$and SRP levels in the $0.5 \mathrm{~m}$ water layer at the sediment surface in both lakes $\left(r^{2}=0.83\right.$ and $\left.0.73, p<0.001, \mathrm{n}=9\right)$. During stratification, the $\mathrm{pH}$-value in the hypolimnion decreased and alkalinity increased (Tab. 3). Both parameters were correlated with the ammonium concentration $\left(r^{2}=0.85\right.$ and 0.78 for $\mathrm{pH}$ and $r^{2}=0.77$ and 0.71 for alkalinity) in the hypolimnion. 


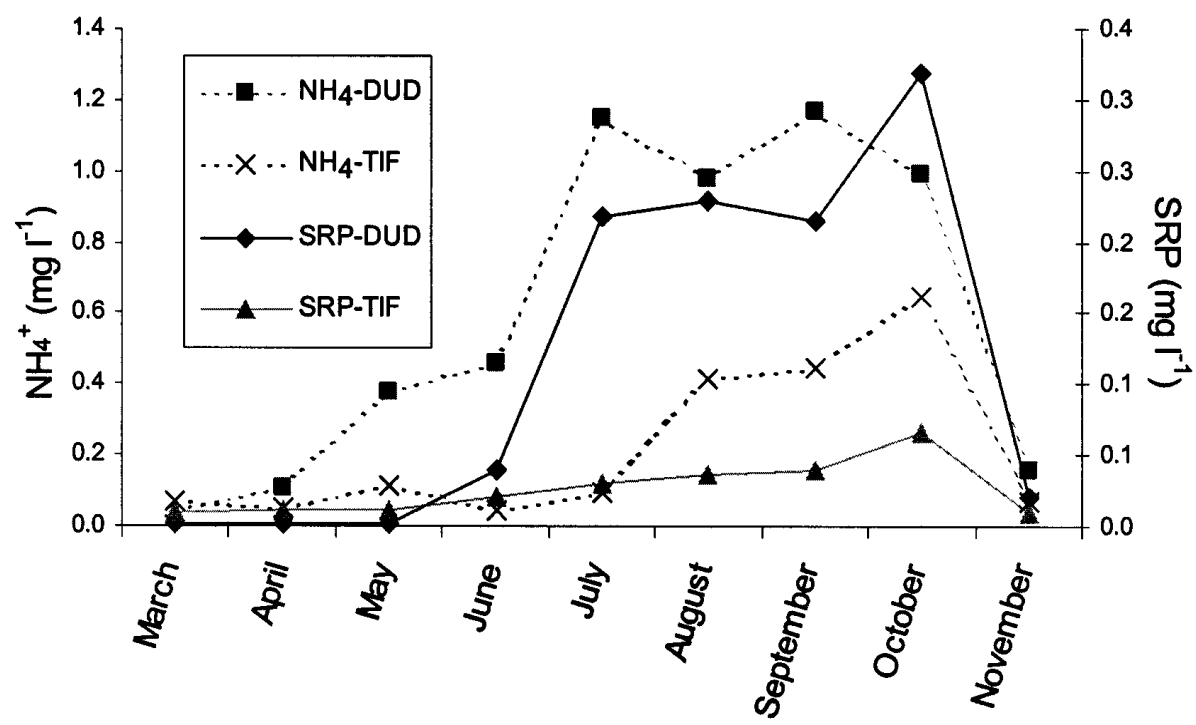

Fig. 3. Ammonium and phosphate concentrations in the deep water in 1998.

Tab. 3. Oxygen saturation, nitrate and nitrite concentration, $\mathrm{pH}$ and alkalinity in the surface water $(0.5 \mathrm{~m}$ - Epi) and in the water layer above sediment (Hypo) in both lakes in 1998.

\begin{tabular}{|c|c|c|c|c|c|c|c|c|c|c|c|}
\hline & & \multicolumn{5}{|c|}{ DUD } & \multicolumn{5}{|c|}{ TIF } \\
\hline & & $\begin{array}{c}\text { nitrate } \\
\left(\mathrm{mg} \mathrm{N}^{-1}\right)\end{array}$ & $\begin{array}{c}\text { nitrite } \\
\left(\mathrm{mg} \mathrm{N} \mathrm{l}^{-1}\right)\end{array}$ & $\mathrm{pH}$ & $\begin{array}{l}\text { oxygen } \\
\text { (\% sat.) }\end{array}$ & $\begin{array}{l}\text { alkalinity } \\
\left(\mathrm{mmol} \mathrm{l}^{-1}\right)\end{array}$ & $\begin{array}{c}\text { nitrate } \\
\left(\mathrm{mg} \mathrm{N}^{-1}\right)\end{array}$ & $\begin{array}{c}\text { nitrite } \\
\left(\mathrm{mg} \mathrm{N} \mathrm{l}^{-1}\right)\end{array}$ & $\mathrm{pH}$ & $\begin{array}{l}\text { oxygen } \\
\text { (\% sat.) }\end{array}$ & $\begin{array}{l}\text { alkalinity } \\
\left(\mathrm{mmol} \mathrm{l}^{-1}\right)\end{array}$ \\
\hline \multirow[t]{2}{*}{ March } & Epi & 0.385 & 0.004 & 8.60 & 129 & 2.75 & 0.169 & 0.001 & 8.33 & 88 & 2.63 \\
\hline & Нуро & 0.352 & 0.011 & 8.46 & 95 & 2.75 & 0.110 & $<0.001$ & 8.11 & 87 & 2.63 \\
\hline \multirow[t]{2}{*}{ April } & Epi & 0.403 & 0.005 & 8.87 & 118 & 2.78 & 0.026 & 0.004 & 8.32 & 98 & 2.67 \\
\hline & Нуро & 0.268 & 0.011 & 8.20 & 84 & 2.74 & 0.105 & $<0.001$ & 8.18 & 77 & 2.69 \\
\hline \multirow[t]{2}{*}{ May } & Epi & 0.340 & 0.009 & 8.79 & 106 & 2.80 & 0.027 & 0.001 & 8.96 & 102 & 2.67 \\
\hline & Нуро & 0.172 & 0.011 & 8.08 & 25 & 3.12 & 0.070 & 0.003 & 7.72 & 43 & 2.71 \\
\hline \multirow[t]{2}{*}{ June } & Epi & 0.142 & 0.015 & 8.61 & 122 & 2.65 & 0.202 & 0.001 & 8.44 & 91 & 2.66 \\
\hline & Нуро & 0.050 & 0.077 & 7.61 & 1 & 3.01 & 0.184 & 0.003 & 7.45 & 1 & 2.70 \\
\hline \multirow[t]{2}{*}{ July } & Epi & 0.006 & 0.002 & 8.35 & 93 & 2.25 & 0.010 & 0.006 & 9.24 & 128 & 2.72 \\
\hline & Нуро & 0.007 & 0.002 & 7.23 & 0 & 3.30 & 0.161 & 0.008 & 7.50 & 0 & 2.75 \\
\hline \multirow[t]{2}{*}{ August } & Epi & 0.004 & 0.002 & 8.75 & 113 & 2.25 & 0.024 & 0.003 & 9.22 & 118 & 2.13 \\
\hline & Нуро & 0.008 & $<0.001$ & 7.24 & 1 & 3.40 & 0.006 & 0.001 & 7.26 & 1 & 3.08 \\
\hline \multirow[t]{2}{*}{ September } & Epi & 0.004 & 0.003 & 8.39 & 94 & 2.46 & 0.010 & 0.005 & 9.10 & 118 & 1.77 \\
\hline & Hypo & 0.007 & $<0.001$ & 7.20 & 1 & 3.53 & 0.007 & 0.003 & 7.28 & 0 & 2.95 \\
\hline \multirow[t]{2}{*}{ October } & Epi & 0.054 & 0.003 & 7.86 & 73 & 2.51 & 0.021 & 0.002 & 7.89 & 109 & 2.21 \\
\hline & Нypo & 0.005 & 0.001 & 7.15 & 1 & 3.79 & 0.014 & $<0.001$ & 7.26 & 1 & 3.09 \\
\hline \multirow[t]{2}{*}{ November } & Epi & 0.031 & 0.007 & 8.00 & 95 & 2.54 & 0.033 & 0.001 & 8.02 & 101 & 2.39 \\
\hline & Нypo & 0.032 & 0.001 & 7.96 & 94 & 2.54 & 0.038 & $<0.001$ & 7.88 & 98 & 2.45 \\
\hline
\end{tabular}

\subsection{Sediment composition and P-binding during spring circulation}

Figure 4 shows the nutrient content in the upper sediment during the spring circulation in 1998. The upper $30 \mathrm{~cm}$ represented approximately the last 80 years ( $\mathrm{Pb}$ dating - Selig et al. 2003a and Erlenkeuser, unpubl. data). The $\mathrm{C}_{\text {org }}$ and $\mathrm{C}_{\text {inorg }}$ contents were different in the two lakes; in Lake DUD the $\mathrm{C}_{\text {org }}$ was higher than in Lake TIF and the $\mathrm{C}_{\text {inorg }}$ lower. The highest content was found in the uppermost $0.5 \mathrm{~cm}$ of the sediment in both lakes. The TP level decreased with increasing depth in the uppermost $10 \mathrm{~cm}$ in both lakes, and was very high in the upper $2 \mathrm{~cm}$. A low variation in the TP was deter- mined at depths of 10 to $30 \mathrm{~cm}$. In contrast to TP, TFe and TAl increased with increasing depth in the upper sediment layers.

The SRP in the pore water showed distinct maximal concentrations at depths between 5 and $10 \mathrm{~cm}$ in Lake TIF, and even higher concentrations were found at this depth in Lake DUD. The $\mathrm{NH}_{4}{ }^{+}$concentration increased continuously with increasing depth in both lakes. The DFe concentration also generally increased with depth, but also demonstrated local differentiation in the upper $10 \mathrm{~cm}$. The DOP was completely different in both lakes: according to the $\mathrm{C}_{\text {org }}$ concentration, the DOP was relatively high in the upper sediment in Lake DUD, whereas below $10 \mathrm{~cm}$ the concentration was very low and con- 


\section{Lake DUD}

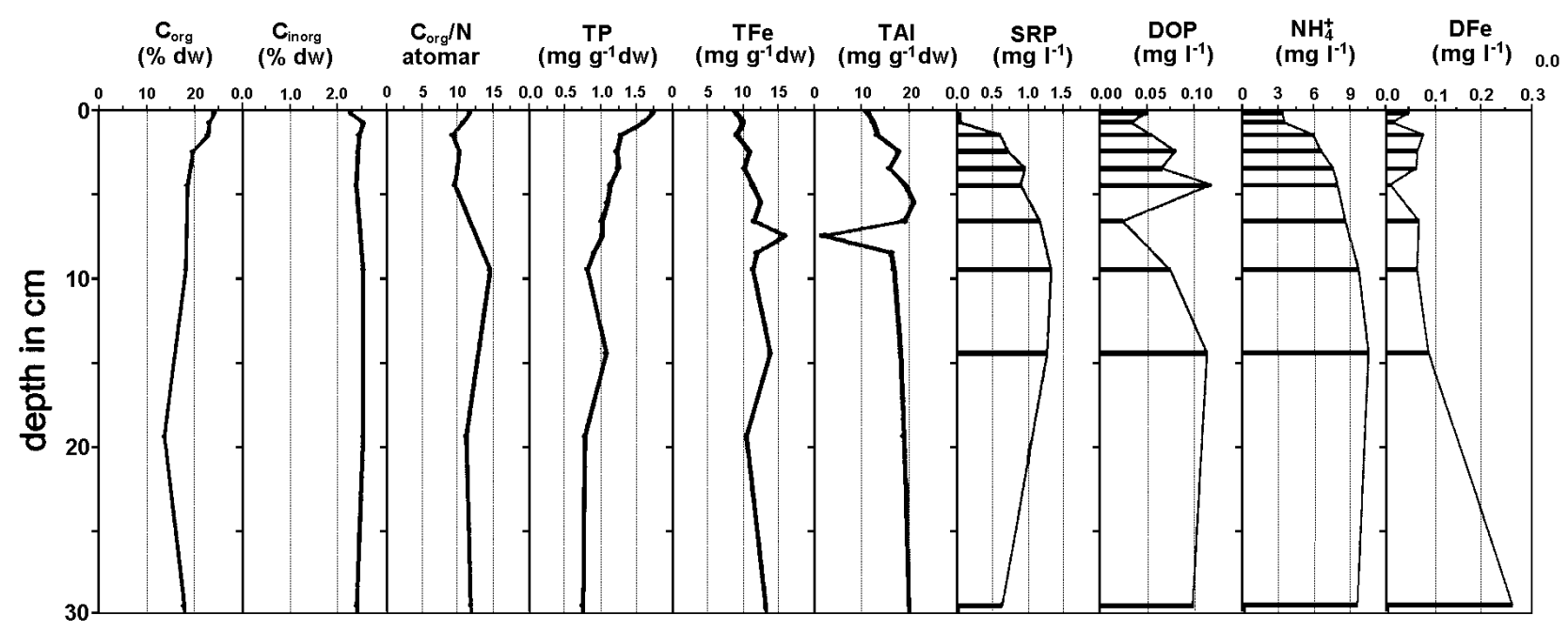

\section{Lake TIF}

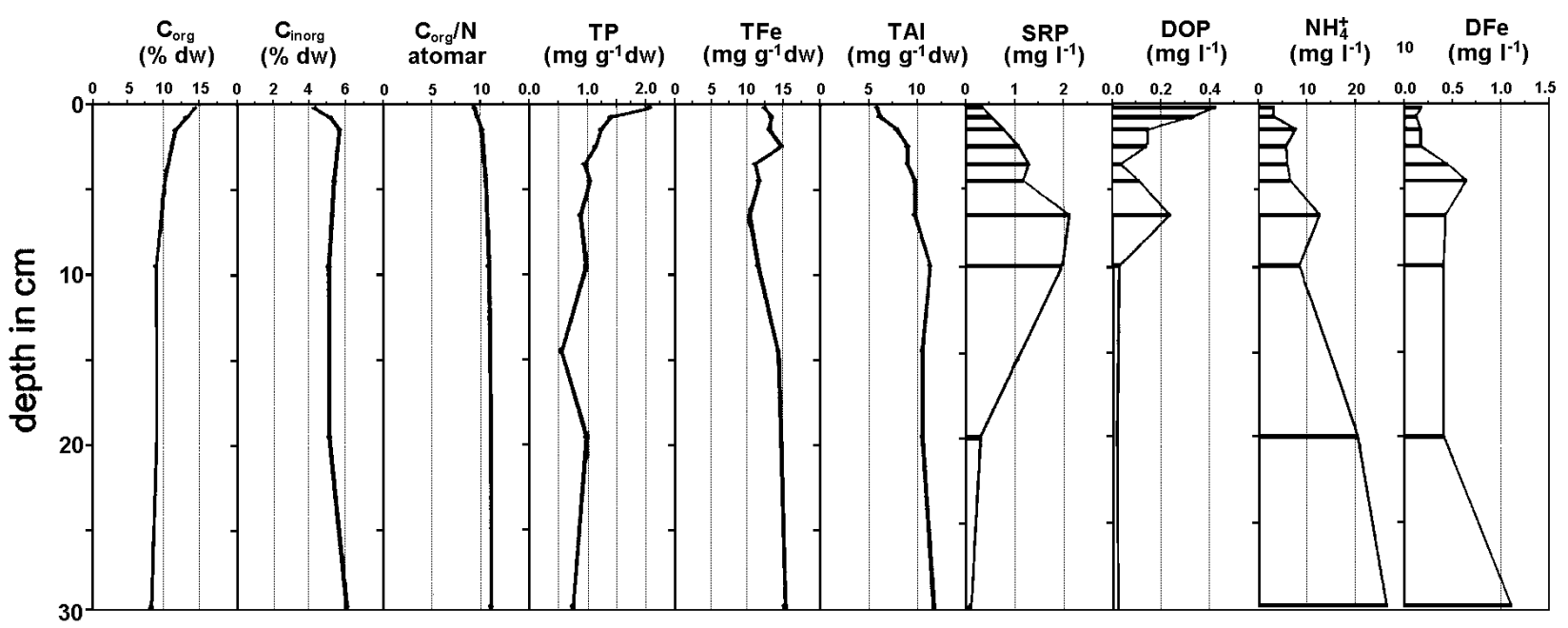

Fig. 4. Profile of total nutrient concentrations and dissolved nutrients in pore water in March 1998 in Lake DUD and Lake TIF.

stant. In Lake TIF no vertical variation for DOP concentration was found in pore water.

In addition to the TP, the sum of the P-fractions also decreased with depth, but the individual fractions showed a different pattern. The distribution of P-species in the sediment of both lakes differed very much (Fig. 5). The labile $\mathrm{P}$ decreased with sediment depth and made up less than 5\% of the TP in all sediment layers of both lakes. The dominant P-fraction in the upper 0-0.5 $\mathrm{cm}$ horizon was the adsorbed-P/Al-P fraction in Lake DUD, amounting up to $27 \%$. This fraction decreased with depth. The Ca-bound $\mathrm{P}$ was the dominant fraction in the sediment layers below $0.5 \mathrm{~cm}$, with $28-41 \%$. The refractory $\mathrm{P}$ level decreased with depth in terms of absolute numbers, but its percentage of the total extractable $\mathrm{P}$ remained the same. The level of redox-sensitive bound $\mathrm{P}$ was two- to three-fold higher in the upper $2 \mathrm{~cm}$ and decreased with increasing depth.
In Lake TIF residual $\mathrm{P}$ and organic $\mathrm{P}$ dominated in all sediment layers and were constantly $32-35 \%$. The Ca bound $\mathrm{P}$ amounted only 10 to $15 \%$ of the extractable $\mathrm{P}$. The redox-sensitive bound $\mathrm{P}$ was low in all sediment layers like in Lake DUD.

\subsection{Variation of P-speciation during summer stratification}

The TP and most of the P-fractions in the surface sediment varied during summer stratification, especially in the upper $0-0.5 \mathrm{~cm}$. The extractable $\mathrm{P}$ ranged from 1.96 to $2.63 \mathrm{mg} \mathrm{P} \mathrm{g}^{-1} \mathrm{dw}$ in Lake DUD (Fig. 6). From March to May the TP increased, subsequently decreasing at the end of summer stratification in September. With the autumnal mixing period the sum of extractable $\mathrm{P}$ increased. In Lake TIF the extractable $\mathrm{P}$ content increased from March to July by about $30 \%$ in the upper $0.5 \mathrm{~cm}$. The $\mathrm{P}$ levels were lower in the second half of 

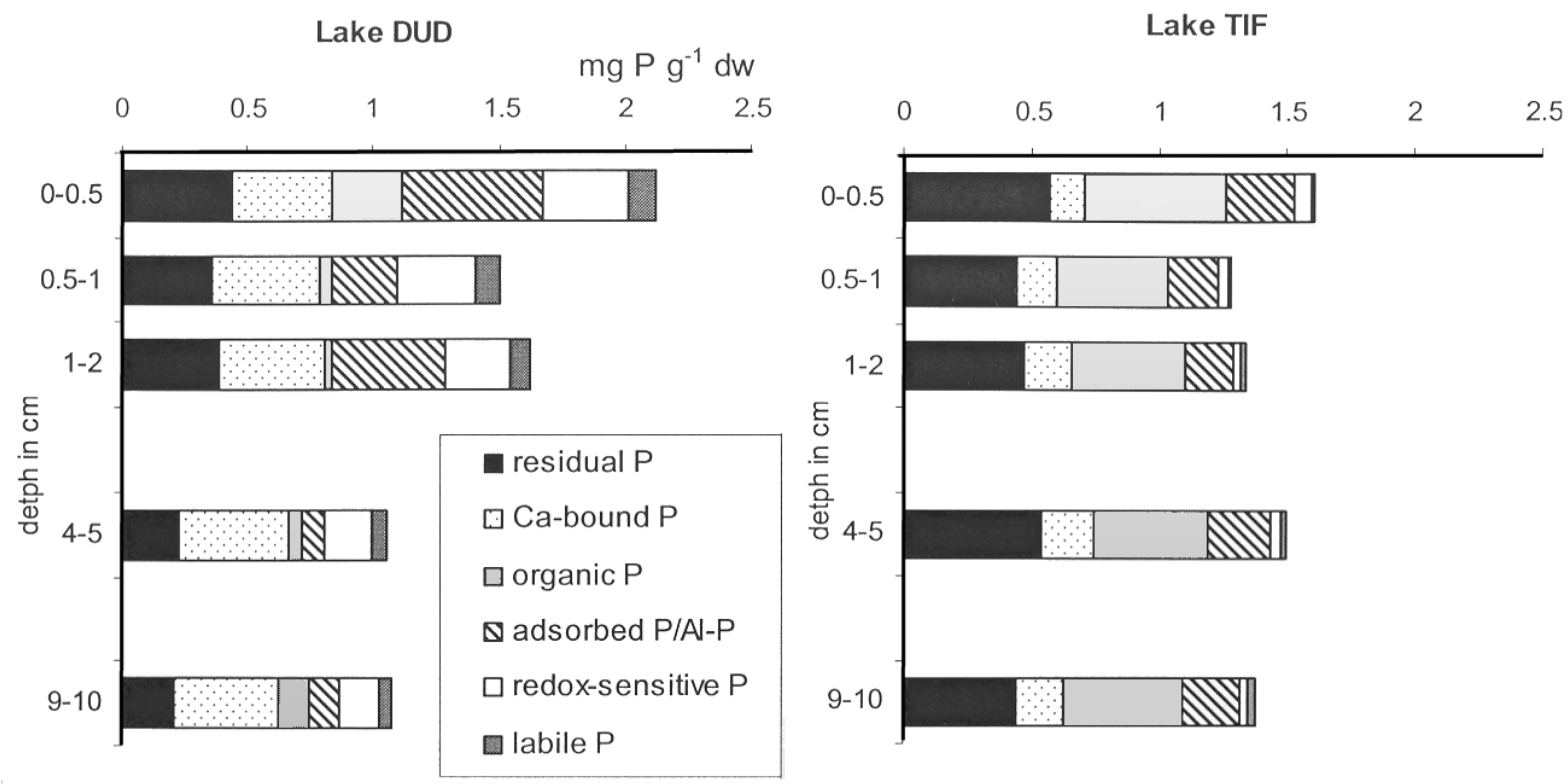

Fig. 5. P-speciation in the uppermost $10 \mathrm{~cm}$ of sediment in March 1998 in Lake DUD (A) and Lake TIF (B).

the year than in July, but higher than measured in March. The labile P decreased between March and May in Lake DUD, whereas it increased from March to September in Lake TIF. Despite its high variability, the labile $\mathrm{P}$ was unimportant for the total balance of P-release due to its low content in both lakes.

Whereas the level of redox-sensitive bound $\mathrm{P}$ did not change during the year in Lake TIF, a decrease was observed during summer stagnation in Lake DUD. P-release started in the layers $0.5-1 \mathrm{~cm}$ and $1-2 \mathrm{~cm}$ in May (Fig. 6) and P decreased about $42-47 \%$. Later, at the end of the summer in September, the redox-sensitive $\mathrm{P}$ in the upper $0.5 \mathrm{~cm}$ also decreased by about $58 \%$. At the end of stratification, not all of the redox-sensitive bound $\mathrm{P}$ was released in each lake. Similar to the redox-sensitive $\mathrm{P}$, the organic $\mathrm{P}$ varied strongly in Lake DUD. In July the organic P was two-fold higher than in March, whereas the increase in organic $\mathrm{P}$ in Lake TIF was lower during the same time period.

\subsection{Calculations of benthic P-release}

The P-release from the sediment of the both lakes was calculated by different methods (Tab. 4). The Preleases varied between 15 and $207 \mathrm{mg} \mathrm{m}^{-2} \mathrm{y}^{-1}$ for Lake DUD and 22 to $55 \mathrm{~m}^{-2} \mathrm{y}^{-1}$ for Lake TIF. The lowest values were calculated from the diagenetic release of labile compounds (variant A) after Penn et al. (1995) for both lakes. For Lake DUD the four methods provided quite different results. The calculation from the redoxsensitive bound P-fraction (4) yielded the highest release - two-fold higher than the calculation based on molecular diffusion. For Lake TIF, molecular diffusion yielded the highest release rate. For this lake a good conformity was found between the three methods (1), (2) and (4).

\section{DISCUSSION}

\subsection{Release of dissolved nutrients and nutrient accumulation in the sediment}

The concentrations of SRP and $\mathrm{NH}_{4}^{+}$increased during summer stratification depending on the oxic condition and nitrate concentration at the sediment surface. In agreement with Gonsiorczyk et al. (1997) and Kleeberg (1997), a strong correlation between these two parameters was observed in the anoxic hypolimnion of both lakes. The P-release in Lake TIF was low and shifted over time. The release started only when nitrate was not detectable in the water layer over the sediment surface after August. The presence of nitrate has been described as a barrier reducing the internal phosphorus load of the hypolimnion in Lake Lyng (Denmark) by Søndergaard et al. (2000). Burley et al. (2001) also observed that a redox-sensitive chemical treatment of sediments reduced the P-release to 6 or $8 \%$ in laboratory studies. This effect was also found in Lake TIF in the first period of summer stratification until August.

The $\mathrm{pH}$-value decreased during the stagnation period, whereas the alkalinity increased. The two parameters characterize the mineralisation of organic matter on the sediment surface. In contrast to the observations made for the water column, no correlations between $\mathrm{SRP}$ and $\mathrm{NH}_{4}^{+}$were found in pore water. This indicates that the SRP concentration in pore water was not mainly governed by mineralisation of organic matter (Boers \& DeBles 1991). 
LAKE DUD
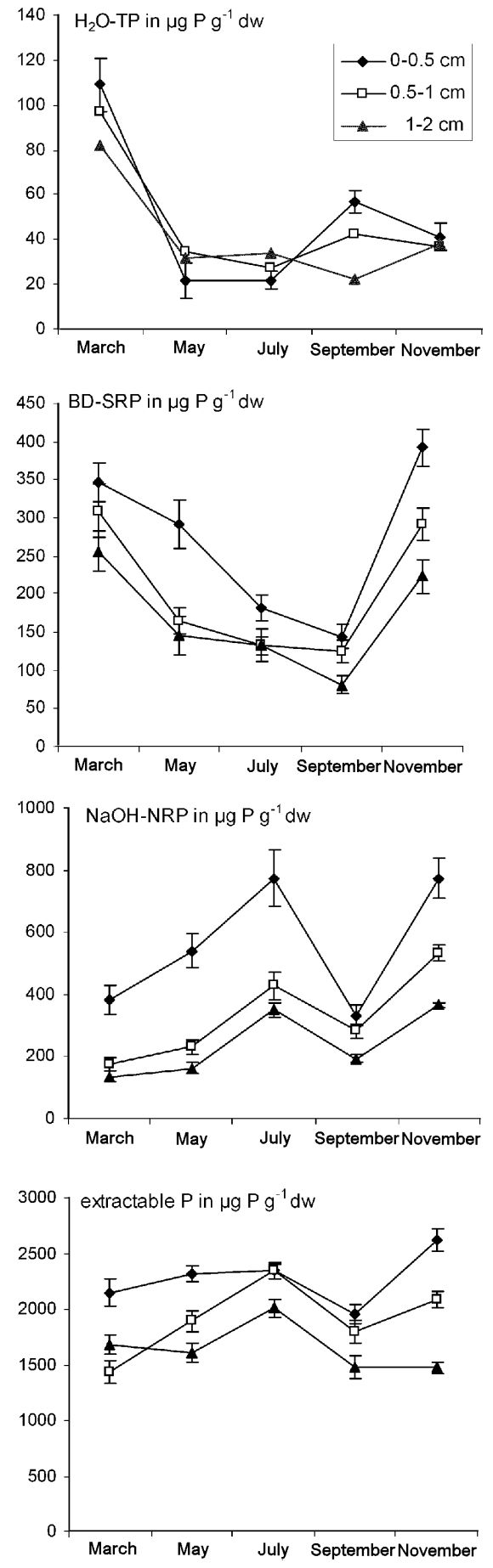

LAKE TIF
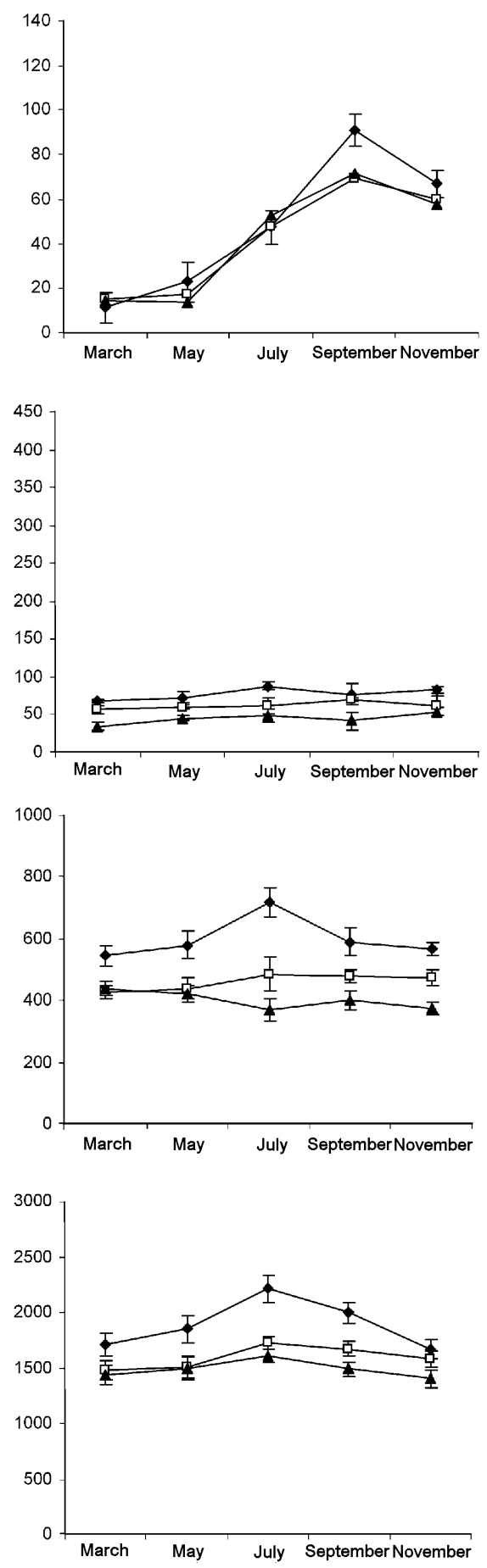

Fig. 6. Seasonal variations of labile $\mathrm{P}$, redox-sensitive bound $\mathrm{P}$, organically bound $\mathrm{P}$ and sum of extractable $\mathrm{P}$ in the sediment horizons $0-0.5 \mathrm{~cm}, 0.5-1 \mathrm{~cm}$ and $1-2 \mathrm{~cm}$ during summer stratification in both lakes.

A comparison of the iron activity product with solubility constants can be used as a criterion for possible mineral formation (Nriagu \& Dell 1974). We found no correlations between SRP and DFe in pore water. Therefore, the released Fe-phosphate complex in the upper sediment under anaerobic conditions was not found in the soluble fraction. Boers and DeBles (1991) investigated the role of complexation of metal iron by DOC in pore water and found that adsorption of metals ions by the sedimentary humic matter may affect the availability of metals in the Loosdrecht Lakes sediments.

In both lakes the $\mathrm{C}_{\text {org }}$ and TP levels were higher in the upper sediment, especially in the uppermost $2 \mathrm{~cm}$. 
Tab. 4. Calculation of benthic P-release by different mathematical methods.

\begin{tabular}{lcc}
\hline Methods of calculation of benthic P-release & $\begin{array}{c}\text { Lake DUD } \\
\left(\mathrm{mg} \mathrm{m}^{-2} \mathrm{y}^{-1}\right)\end{array}$ & $\begin{array}{c}\text { Lake TIF } \\
\left(\mathrm{mg} \mathrm{m}^{-2} \mathrm{y}^{-1}\right)\end{array}$ \\
\hline Molecular diffusion & 90 & 55 \\
Mean accumulation rate of SRP in the hypolimnion & 15 & 47 \\
including PP in layer of phototrophic sulfur bacteria & 100 & \\
Diagenetic release of labile compounds & 15.9 & 22.8 \\
$\quad$ Variant A & 30.0 & 25.6 \\
$\quad$ Variant B (organic P including in refractory P) & 207.6 & 40.9 \\
Redox sensitive fraction (BD fraction) & \\
\hline
\end{tabular}

The greater deposition of phosphorus explains the higher contribution of organically bound $\mathrm{P}$ in the uppermost $2 \mathrm{~cm}$ of sediment. The $\mathrm{NaOH}-\mathrm{NRP}$ fraction characterized the organic P (Selig \& Schlungbaum 2002) or was described by Penn et al. (1995) as the extractable biogenic fraction. The redox-sensitive $\mathrm{P}$, which is the most important fraction contributing to P-release under anoxic conditions, was $19 \%$ of TP in the upper sediment in Lake DUD and only $6 \%$ in Lake TIF. The absolute content and percentage decreased with increasing depth. Especially in the upper $1 \mathrm{~cm}$ the values were higher. The low SRP concentration in the pore water is caused by an oxic sediment layer formed by spring circulation (Fig. 4B). Below the 1-2 cm sediment layer the SRP concentrations increased erratically. Rydin \& Brunberg (1998) described the formation of an effective oxic barrier with a Fe:P ratio (by weight) of above 15 . The Fe:P ratio was $6: 1$ and $8: 1$ in the upper $0.5 \mathrm{~cm}$ layer of both lakes and increased with the depth.

\subsection{Variation of P-binding in the upper sediment during summer stratification}

In both lakes the amount of $\mathrm{P}$ released from the sediment depends on the oxygen concentration and redox potential. But only in Lake DUD did the concentration of redox-sensitive bound $\mathrm{P}$ decrease during summer stratification. Therefore, only in this lake was the reduction of $\mathrm{FeOOH}$-phosphate complex important for the P-release during summer stratification. In agreement with the results of Gonsiorczyk et al. (2001), we found that the release of redox-sensitive $\mathrm{P}$ from the sediment layers down to $2 \mathrm{~cm}$ depth was important for the anoxic release during the summer stagnation in Lake DUD. In accordance with the investigation of Penn \& Auer (1997) not all BD-extractable P was released under anoxic conditions. Whereas Penn \& Auer (1997) were able to detect oxygen down to a few centimetres under the sediment surface, no oxygen was found in the upper layers of sediment in DUD. Ulrich (1997) described some portion of the BD-SRP as refractory and thus not suitable for transformation into SRP. Psenner et al. (1984), the originators of the applied fractionation method, described the partial extraction of Al-P and hot labile organic phosphorus with the BD-fraction.

The explanation for the fact that there was no decrease in redox-sensitive bound P in Lake TIF was that the concentration in spring was very low. Under oxic conditions, no oxic FeOOH-phosphate complex was created. The TFe concentration and the Fe/P ratio were not lower in Lake TIF than in Lake DUD. The stable binding of iron as FeS can be discussed as the reason for this effect.

The TP and P-fractions in the upper $1 \mathrm{~cm}$ of the sediment varied considerably during the summer stratification in both lakes. Simultaneous to the P-release from the sediment through the change in redox potential at the sediment's surface, PP is re-deposited from the epilimnion into the sediment. The sedimentation of organic material is particularly high in the spring and summer when algae blooms start to decay. This occurrence is described by Penn \& Auer (1997), who recorded higher sedimentation rates in July and August for Lake Onondaga than in the other months. Goedkoop and Pettersson (2000) observed an accumulation of organic $\mathrm{P}(\mathrm{NaOH}-\mathrm{NRP})$ and loosely bound $\mathrm{P}\left(\mathrm{NH}_{4} \mathrm{Cl}\right)$ in the surface sediment of Lake Erken through the sedimentation of diatoms. For both lakes investigated in this study, the NaOH-NRP fraction increased from March to September in the upper $1 \mathrm{~cm}$. Although sedimentation rates were not determined for either lake, a higher phytoplankton biomass was recorded in the epilimnion in the summer (from June to August) of 1997-1999 (Hübener, unpubl.).

In addition to the increase in organic $\mathrm{P}$ levels through the sedimentation of organic material, other processes which cause a reduction in the $\mathrm{NaOH}-\mathrm{NRP}$ fraction can occur when the redox potential changes: bacteria can store polyphosphate granules under oxic conditions which are released when the conditions become anoxic. Polyphosphates have also been extracted by $\mathrm{NaOH}$ and identified in the $\mathrm{NaOH}-\mathrm{NRP}$ fraction (Uhlmann et al. 1990). The release of these storage granules can play an important role in $\mathrm{P}$ release by shifting conditions from oxic to anoxic (Waara et al. 1993). The release of polyphosphate storage takes place at the same time as the reduction of the FeOOH-phosphate complex. For this reason, these two release processes cannot be differentiated through an analysis of the SRP-concentration in the water by shifting the redox conditions. The presence or release from intracellular storage as polyphosphate in bacteria is only quantifiable using ${ }^{31} \mathrm{P}$ NMR spectroscopy (Hupfer et al. 1995a; Baldwin 1996), not by sequential chemical extraction. 
Such data were not available from our investigation, but the release of stored polyphosphate must be considered to be a possible method of anoxic P-release, especially for Lake TIF, for which no redox-sensitive release of FeOOH-phosphate complex was found. Another aspect is the mineralisation of organic matter and phytate under anoxic conditions. $\mathrm{NaOH}$ also extracted organic $\mathrm{P}$ and phytate. The existence and importance of phytate in freshwater sediments is a matter of some controversy (Goedkoop \& Pettersson 2000), and our results unfortunately shed no light on the subject.

The concentration of HCl-P (Ca-bound P) shows a similar pattern. In Lake DUD the concentrations was higher as in Lake TIF. The Ca-bound $\mathrm{P}$ fraction charaterised the precipitation with $\mathrm{Ca}^{2+}$ as apatite. In Lake DUD the $\mathrm{Ca}$ concentration in epilimnion was higher (54-75 $\mathrm{mg} \mathrm{l}^{-1}$ ) as in Lake TIF (35-58 $\mathrm{mg} \mathrm{l}^{-1}$ ).

A possible release of apatite caused by the observed $\mathrm{pH}$ drop - described by Golterman (1998) - could not be demonstrated through the fractionation studies. Furthermore the similar concentrations of Ca-bound $\mathrm{P}$ in the deep sediments described the stability of this $\mathrm{P}$ fraction in both lakes.

\subsection{Calculations of benthic P-release}

The exact calculation of benthic P-release is necessary to compare external and internal phosphorus loading and to determine optimal lake restoration strategies. The four different calculation methods yielded different release rates.

The calculations of P-release using the concentration gradient at the sediment-water interface (1) is based on Fick's law and were used by the most field studies (Kleeberg 1997; Klump et al. 1997). The total flux of dissolved compounds across the sediment-water interface includes advection, bioturbation, irrigation, physical wave activity and current effects (Belzile et al. 1996). In consideration of these aspects, the P-release based on the calculation of molecular diffusion is mostly an underestimation of P-release on the sediment water interface. Another problem is the variability of SRP in pore water caused by the reduction of the redox potential and changing of $\mathrm{pH}$ in the upper sediment layer.

The calculation method (2) based on the mean accumulation rate of SRP in the hypolimnion during summer stratification has been used by many researchers, by laboratory investigation as well as in field studies (Nürnberg 1987; Gonsiorczyk et al. 2001). The problem with this method is the calculation of only the dissolved nutrients. The released SRP can be transformed into particulate P, e.g. by heterotrophic bacterioplankton (Morris \& Lewis 1992) or by phototrophic bacterioplankton (Baneras \& Garcia-Gil 1998). For Lake DUD the transformation of released SRP by the biomass of phototrophic sulfur bacteria was described by Selig et al. (2003b). A calculation of the P-release using the TP-concentration of the hypolimnion was not possible, because the settling particulate phosphorus would be included. By including only the particulate $\mathrm{P}$ from the phototrophic bacterial mat in the calculation, the $P$ release rate increased in Lake DUD and was of the same order of magnitude as the calculation based on Fick's law.

The calculation of the diagenetic release of labile $\mathrm{P}$ components (3) was based on a model by Penn et al. (1995). The authors describe a stable composition between refractory $\mathrm{P}$ and sedimented $\mathrm{P}$ at the time of deposition. The different definition of refractory $\mathrm{P}$ based on different P-fractions complicates the calculation of P-release. Both variants of the calculation yielded the lowest P-release in both lakes. One explanation might be that this model neglects possible changes in the redox condition at the sediment-water interface. A comparison of both variants showed an important difference only in Lake DUD. The definition of the NaOH-NRP fraction as a refractory and constant P-pool is doubtful. In this fraction, e.g. $\mathrm{P}$ bound to humic substances (Uhlmann et al. 1990), $\mathrm{P}$ which had been accumulated in microorganisms (Waara et al. 1993) or in special organic compounds such as phospholipids and polyphosphates (Baldwin 1996) were extracted. Boström et al. (1985) described the NaOH-NRP fraction as the most dynamic fraction. For this reason, the P-fraction was not considered as part of refractory $\mathrm{P}$ in Lakes DUD and TIF.

Beside on the calculation according to Penn et al. (1995) the results of $P$ fractionation can used for an another method: the potential anoxic P-release (4) can be calculated by analysis of redox sensitive bound $\mathrm{P}$ at the beginning of the summer stratification. This P-release was more definite as potential release. The highest Prelease rates for Lake DUD were calculated using this method. Gonsiorczyk et al. (2001) calculated a ten-fold higher P-release for Lake Stechlinsee when using the BD-SRP fraction than when using the other methods described in this paper. Beside on the potential character of this calculation, the method of the anoxic P-release based on the BD-SRP fraction is clearly unrealistic. Psenner et al. (1984) proposed subtracting a stable BDSRP value from the deeper, permanently anoxic sediment layers as a correction. After taking the BD-SRP concentration in the $4-5 \mathrm{~cm}$ and $9-10 \mathrm{~cm}$ sediment layers into consideration as a background value, $75 \%$ of the $\mathrm{BD}-\mathrm{SRP}$ in the surface sediment is released during summer stratification in Lake DUD. The calculated $\mathrm{P}$ release is thus reduced to $155 \mathrm{mg} \mathrm{m}^{-2} \mathrm{y}^{-1}$. This value was still greater than the other calculated release rates. In Lake TIF only a marginal variation in the BD-SRP fraction in the upper $2 \mathrm{~cm}$ was observed and cannot statistically be interpreted as a relevant difference.

None of these methods alone is suitable for accurately and definitively calculating the P-release rate; a combination of several methods provides the best solution. For Lake TIF, a good conformity was observed 
between the three calculation methods: molecular diffusion based on Fick's law, mean accumulation rate of SRP in the hypolimnion, and the redox-sensitive fraction. For this lake the $\mathrm{P}$ release can be confidently described as 40-55 $\mathrm{mg} \mathrm{m}^{-2} \mathrm{y}^{-1}$. For Lake DUD, a good agreement was also found between the calculations based on molecular diffusion and on the mean accumulation rate of SRP in the hypolimnion by including the PP of phototrophic sulfur bacteria. Calculations based on the diagenetic release of labile P-compounds underestimated the P-release rate and depended on the different definition of labile $\mathrm{P}$ compounds.

The different trophic status of both lakes cannot only be explained by the P-release rates. In the mesotrophic Lake DUD a higher and more redox-dependent P-release was found than in the eutrophic Lake TIF. On the other hand, the accumulation rate of dissolved $\mathrm{P}$ in the hypolimnion was lower in Lake DUD and most of the released SRP was accumulated in photoautotrophic sulfur bacteria biomass.

\section{CONCLUSION}

In both lakes, SRP was released from the profundal sediment under anoxic conditions during the summer stratification. The mechanisms of phosphorus release differed in both lakes - only in Lake DUD could the redox-sensitive P-release be proved.

The applied four calculation methods described very different P-release rates, especially for Lake DUD. The reason for this effect may be the development of phototrophic sulfur bacteria in Lake DUD and their function as a "particulate nutrient filter". By including this particulate phosphorus in the accumulation rate in the hypolimnion, the molecular diffusion rates and SRP-accumulation rate showed a good agreement. Three calculation methods showed a good conformity in Lake TIF: the molecular diffusion rates, SRP-accumulation rates and the calculation based on the redox-sensitive fraction. The accurate calculation of benthic P-release therefore requires a combination of different methods.

\section{ACKNOWLEDGMENTS}

All this would not have been possible without Fred Brezsinski's technical assistance in the field and Sabine Stolle's technical assistance in the laboratory.

\section{REFERENCES}

Andersen, J.M. 1976. An ignition method for determination of total phosphorus in lake sediments. Wat. Res., 16: 119-126.

Baldwin, D.S. 1996. The phosphorus composition of a diverse series of Australian sediments. Hydrobiologia, 335: 63-73.

Baneras, L. \& L.J. Garcia-Gil. 1998. Environmental and physiological factors affecting the uptake of phosphate by Chlorobium limicola. Arch. Microbiol., 170: 252-258.

Barbanti, A., M.C. Bergamini, F. Frascari, S. Miserocchi \& G. Rosso. 1994. Critical aspects of sedimentary phosphorus chemical fractionation. J. Environ. Qual., 23: 1093-1102.

Belzile, N., J. Pizarro, M. Filella \& J. Buffle. 1996. Sediment diffusive fluxes of $\mathrm{Fe}, \mathrm{Mn}$, and $\mathrm{P}$ in a eutrophic lake: Contribution from lateral vs bottom sediments. Aquat. Sci., 58(4): 327-354.
Boers, P.C.M. \& F. De Bles. 1991. Ion concentrations in interstitial water as indicators for phosphorus release processes and reactions. Wat. Res., 25: 591-598.

Boers, P.C.M., W. Van Raaphorst \& D.T. Van der Molen. 1998. Phosphorus retention in sediments. Wat. Sci. Technol., 37: 31-39.

Boström, B. 1984. Potential mobility of phosphorus in different types of lake sediments. Int. Revue ges. Hydrobiol., 69(4): 457-474.

Boström, B., I. Ahlgren \& R. Bell. 1985. Internal nutrient loading in a eutrophic lake, reflected in seasonal variations some sediment parameters. Verh. int. Ver. Limnol., 22: 3335-3339.

Burley, K.L., E. Prepas \& P.A. Chambers. 2001. Phosphorus release from sediments in hardwater eutrophic lakes: the effect of redox-sensitive and -insensitve chemical treatments. Freshwat. Biol., 46: 1061-1074.

De Pinto, J.V., T.C. Young \& S.C. Martin. 1981. Algal available phosphorus in suspended sediments in Minnesota lakes. Limnol. Oceanogr., 21(2): 259-284.

DEV. 1992. Deutsche Einheitsverfahren zur Wasser, Abwasser- und Schlammbehandlung. - DIN 38409/7, 1979.

Dunemann, L. \& G. Schwedt. 1984. Zur Analytik von Elementbindungsformen in Bodenlösungen mit Gelchromatographie und chemischen Reaktionsdetektoren. Fres. Z. Anal. Chem., 317: 394-399.

Einsele, W. 1936. Über die Beziehungen des Eisenkreislaufes zum Phosphatkreislauf im eutrophen See. Arch. Hydrobiol., 29: 664-686.

Einsele, W. 1938. Über chemische und kolloidchemische Vorgänge in Eisen-Phosphat-Systemen unter limnochemischen und limnogeologischen Gesichtspunkten. Arch. Hydrobiol., 33: 361-387.

Gächter, R., J.S. Meyer \& A. Mares. 1988. Contribution of bacteria to release and fixation of phosphorus in lake sediments. Limnol. Oceanogr., 33: 1542-1558.

Gliwicz, Z.M. 1979. Metalimnetic gradients and trophic state of lake epilimnia. Mem. Ist. ital. Idrobiol., 37: 121-143.

Goedkoop, W. \& K. Pettersson. 2000. Seasonal changes in sediment phosphorus forms in relation to sedimentation and benthic bacterial biomass in Lake Erken. Hydrobiologia, 431: 41-50.

Golterman, H.L. 1982. Differential extraction of sediment phosphorus with NTA solutions. Hydrobiologia, 92: 683-687.

Golterman, H.L. 1998. The distribution of phosphate over iron-bound and calcium-bound phosphate in stratified sediments. Hydrobiologia, 364: 75-81.

Golterman, H.L. 2001. Phosphate release from anoxic sediments or "what did Mortimer really write"? Hydrobiologia, 450(1-3): 99-106.

Golterman, H.L., J. Paing, L. Serrano \& E. Gomez. 1998. Presence of and phosphate release from polyphosphates or phytate phosphate in lake sediments. Hydrobiologia, 364 : 99-104.

Gonsiorczyk, T., P. Casper \& R. Koschel. 1997. Variations of phosphorus release from sediments in stratified lakes. Water Air Soil Pollut., 99: 427-434.

Gonsiorczyk, T., P. Casper \& R. Koschel. 2001. Mechanisms of phosphorus release from the bottom sediment of the oligotrophic Lake Stechlin: Importance of the permanently oxic sediment surface. Arch. Hydrobiol., 151(2): 203-219.

Hartikainen, H. 1979. Phosphorus and its reactions in terrestrial soils and lake sediments. Journal of the Scientific Agricultural Society of Finland, 51: 537-624.

Hieltjes, A.H.M. \& L. Lijklema. 1980. Fractionation of inorganic phosphorus in calcareous sediments. J. Environ. Qual., 8: 130-132.

Hupfer, M., R. Gächter \& H. Rügger. 1995a. Polyphosphate in lake sediments: 31P NMR spectroscopy as a tool for its identification. Limnol. Oceanogr., 40(3): 610-617. 
Hupfer, M., R. Gächter \& R. Giovanoli. 1995b. Transformation of phosphorus species in settling seston and during early sediment diagenesis. Aquat. Sci., 57(4): 305-324.

Kleeberg, A. 1997. Interactions between benthic phosphorus release and sulphur cycling in lake Scharmützelsee (Germany). Water Air Soil Pollut., 99: 391-399.

Klump, J.V., D.N. Edgington, P.E. Sager \& D.M. Robertson 1997. Sedimentary phosphorus cycling and a phosphorus mass balance for the Green Bay (Lake Michigan) ecosystem. Can. J. Fish. Aquat. Sci., 54: 10-26.

LAWA 1998. "Gewässerbewertung - Stehende Gewässer". Richtlinie zur Bewertung von natürlich entstandenen Seen nach trophischen Kriterien. - Länderarbeitsgemeinschaft Wasser: $74 \mathrm{pp}$.

Malcolm-Lawes, D.J. \& H.W. Koon. 1990. Determination of orthophosphate in water and soil using a flow analyser. Analyst, 15: 65-67.

Maue, G. 1989. Stoffbelastung in Fließgewässern. Paul Parey Verlag, Hamburg-Berlin: 273-344.

Morris, D.P. \& W.M. Lewis. 1992. Nutrient limitation of bacterioplankton growth in Lake Dillon, Colorado. Limnol. Oceanogr., 37: 1179-1192.

Mortimer, C. 1941. The exchange of dissolved substances between mud and water in lakes I. J. Ecol., 29: 280-329.

Mortimer, C. 1942. The exchange of dissolved substances between mud and water in lakes II. J. Ecol., 30: 147-201.

Nakamura, T., H. Yamaguchi \& S. Ohashi. 1980. Problems on use of autoanalyser for condensed phosphates. $J$. of Occup. Environ. Health (Japan)., 2(2): 199-205.

Nriagu, J.O. \& C.I. Dell. 1974. Diagenetic formation of iron phosphates in recent lake sedimetns. Am. Mineral., 59: 934-946.

Nürnberg, G.K. 1987. A comparison of internal phosphorus loads in lakes with anoxic hypolimnia: Laboratory incubation versus in situ hypolimnetic phosphorus accumulation. Limnol. Oceanogr., 32(5): 1160-1164.

Nürnberg, G.K. 1988. Prediction of phosphorus release rates from total and reductant soluble phosphorus in anoxic lake sediments. Can. J. Fish. Aquat. Sci., 45: 453-462.

Penn, M.R., M.T. Auer, E.L. Van Orman \& J.J. Korienek. 1995. Phosphorus diagenesis in lake sediments: investigations using fractionation techniques. Mar. Freshw. Res., 46: 89-99.

Penn, M.R. \& M.T. Auer. 1997. Seasonal variability in phosphorus speciation and deposition in a calcareous, eutrophic lake. Mar. Geol., 139: 47-59.

Pettersson, K. 1998. Mechanisms for internal loading of phosphorus in lakes. Hydrobiologia, 373/374: 21-25.

Psenner, R., R. Pucsko \& M. Sager. 1984. Die Fraktionierung organischer und anorganischer Phosphorverbindungen von Sedimenten - Versuch einer Definition ökologisch wichtiger Fraktionen. Arch. Hydrobiol. Suppl., 70: 111-155.

Rohde, K.H. \& D. Nehring. 1979. Ausgewählte Methoden zur Bestimmung von Inhaltsstoffen im Meer- und Brackwasser. Geod. Geoph. Veröff. IV., 27: 24-27.

Ruban, V., J.F. Lopez-Sanchez, P. Pardo, G. Rauret, H. Muntau \& P. Quevauviller. 1999. Selection and evaluation of sequential extraction procedures for the determination of phosphorus forms in lake sediment. J. Environ. Monit., 1: 51-56.

Rydin, E. \& A.K. Brunberg. 1998. Seasonal dynamics of phosphorus in Lake Erken surface sediments. Arch. Hydrobiol., 51: 157-167.

Sas, H. 1989. Lake restoration by reduction of nutrient loading: expectations, experiences, extrapolations. Academia Verlag Richarz, Sankt Augustin: 497 pp.

Schlungbaum, G. 1979. Untersuchungen über die Sedimentqualität in den Gewässern der Darß-Zingster Boddenkette unter besonderer Berücksichtigung der Stoffaustauschprozesse zwischen Wasser und Sediment. Habilitationsschrift. Fachbereich Biologie. Universität Rostock: 134 pp.

Selig, U. \& G. Schlungbaum. 2002. Longitudinal patterns of phosphorus and phosphorus binding in sediment of a lowland lake-river system. Hydrobiologia, 472: 67-76.

Selig, U., Th. Hübener, A. Schwarz. \& Th. Leipe 2003a. The environmental history investigations of a postglacial dimictic lake in North Germany. Proceeding Internat. Assoc. Limnology, 28: 1340-1344.

Selig, U., T. Hübener, R. Heerkloss \& H. Schubert 2003b. Vertical gradient of nutrients in two dimictic lakes - influence of phototrophic sulfur bacteria on the nutrient balance. Aquat. Sci.: (accepted).

Sinke, A., A.A. Cornelese, P. Keizer, O.F.R. Van Tongeren \& T.E. Cappenberg. 1990. Mineralization, pore water chemistry and phosphorus release from peaty sediments in the eutrophic Loosdrecht lakes, Netherlands. Freshwat. Biol., 23: 587-599.

Songdergaard, M., E. Jeppesen \& J.P. Jensen. 2000 Hypolimnetic nitrate treatment to reduce internal phosphorus loading in a stratified lake. Lake and Reservoir Management, 16(3): 195-204.

Stookey, L.L. 1970. Ferrozine - a new spectrophotometric reagent for iron. Anal. Chem., 42(7): 779-781.

Uhlmann, D., I. Röske, M. Hupfer \& G. Ohms. 1990. A simple method to distinguish between polyphosphate and other phosphate fractions of activated sludge. Wat. Res., 24(1): 1355-1360.

Ulrich, K.-U. 1997. Effects of land use in the drainage area on phosphorus binding and mobility in the sediments of four drinking-water reservoirs. Hydrobiologia, 345: 21-38.

Verardo, D.J., P.N. Froelich \& A. McIntyre. 1990. Determination of organic carbon and nitrogen in marine sediments using the Carlo Erba NA-1500 Analyser. Deep Sea Res., 37: 157-165.

Waara, T., M. Jansson \& K. Petterson. 1993. Phosphorus composition and release in sediment bacteria of the genus Pseudomonas during aerobic and anaerobic conditions. Hydrobiologia, 253: 131-140.

Welch, E.B. \& G.D. Cooke. 1995. Internal phosphorus loading in shallow lakes: importance and control. Lake and Reservoir Management, 11: 273-281.

Williams, J.D.H., J.K. Syers, R.F. Harris \& D.E. Armstrong. 1971. Fractionation of inorganic phosphate in calcareous lake sediments. Soil Science Society of America Proceedings, 35: 250-255. 